\title{
Comparision of different cell cultures for replication of infectious laryngotracheitis virus from chickens
}

\author{
Comparação de diferentes cultivos celulares para a replicação do vírus da laringotraqueíte infecciosa das \\ galinhas
}

\section{Cristiana Portz ${ }^{1}$, Laura Lopes de Almeida ${ }^{1}$, Alfredo Bianco J únior ${ }^{1}$, Herbert Reck ${ }^{1}$, Ana Cláudia Franco ${ }^{2} \&$ Cláudio Wageck Canal ${ }^{1}$}

\begin{abstract}
The propagation of infectious laryngotracheitis virus (ILTV) has been described using primary cell cultures derived from chicken embryo liver and kidney or embryonated eggs, but these cultures use Specific Pathogen Free (SPF) eggs that are time and cost expensive. Since cell line cultures are easier to maintain in laboratory conditions, the growth of ILTV was evaluated in five different cell cultures: chicken embryo related cells (CER), a cell hybrid derived from chicken embryo fibroblasts cells and BHK-21; Vero, from African green monkey kidney cells; HD11, a chicken macrophage cell line; CEC-32, an avian fibroblast cell line and a primary cell culture of chicken embryo fibroblasts (CEF). Cytophatic effect was observed until 96 hours following inoculation and the detection of the viral DNA was performed by PCR. The HD11 and CEC-32 cell lines did not support the virus growth but CEF and Vero, as already described were permissive cultures for propagation of ILTV. The results also showed that the CER cell line can be used for primary isolation and replication of ILTV.
\end{abstract}

Keywords: Infectious Laryngotracheitis Virus, Virus Isolation, Cell Culture, Gallid Herpesvirus 1, Diagnosis.

\section{RESUMO}

A propagação do vírus da laringotraqueíte infecciosa tem sido descrita usando culturas de células primárias derivadas de fígado e rim de embrião de galinha ou ovos embrionados, entretanto, essas culturas necessitam de ovos livres de patógenos específicos (SPF) que tomam tempo e custam caro. Desta maneira, culturas de células de linhagem são mais fáceis de manter em laboratório e conduzir os experimentos. A propagação do ILTV foi avaliada em cinco diferentes cultivos celulares: chicken embryo related cells (CER), que é uma linhagem híbrida derivada de fibroblasto de embrião de galinha e BHK-21; a linhagem Vero, derivada de células de rim de macaco verde africano; HD11, uma linhagem de células de macrófagos de galinha; CEC32, uma linhagem de fibroblasto de ave; e um cultivo primário de fibroblasto de embrião de galinha (CEF). O efeito citopático foi observado até 96 horas pós-inoculação e a presença do DNA viral foi realizada por PCR. Os cultivos de linhagem HD11 e CEC-32 não propiciaram a propagação viral e os cultivos celulares de CEF e Vero, como previamente descrito, mostraram ser permissíveis à replicação do VLTI. Os resultados também demonstram que a linhagem celular CER também pode ser utilizada para o isolamento e replicação do VLTI.

Descritores: Vírus da Laringotraqueíte Infecciosa, Isolamento Viral, Cultivos Celulares, Gallid Herpesvirus 1, Diagnóstico.

${ }^{1}$ Laboratório de Virologia, Faculdade de Veterinária, Universidade Federal do Rio Grande do Sul (UFRGS), Porto Alegre, RS/Brazil. ${ }^{2}$ Laboratório de Virologia, Instituto de Ciências Básicas da Sáude (ICBS) - UFRGS. CORRESPONDENCE: C.W. Canal [claudio.canal@ ufrgs.br] Fax: + (55) 51 3308 7305]. 
INTRODUCTION

Infectious laryngotracheitis virus (ILTV) is classified as a member of the family Herpesviridae in the subfamily Alphaherpesvirinae. The virus is taxonomically identified as Gallid herpesvirus 1 (GaHV1), genus Iltovirus, which genome is a linear doublestranded DNA with $155 \mathrm{~kb}[10,13]$. ILTV infection is characterized by signs of respiratory distress in chickens that may result in significant mortality and loss of productivity. The first report of ILTV in Brazil dates from 1974 and since then some cases were reported based on serological, virological and histophatological tests $[2,9,18,21]$. The isolation of ILTV from field material has been described using embryonated chicken eggs inoculated in the chorioallantoic membrane (CAM) [12], and primary cell cultures derived from chicken embryo liver (CEL), chicken embryo kidney (CEK), chicken embryo fibroblast (CEF) and a cell line derived from an African green monkey kidney (Vero) [10]. However, due to the short life span, cost and the time spent to produce primary cell cultures, an option to enhance the number of viral particles can be the use of a continuous cell line. Such cell lines are especially relevant to many laboratory procedures that require high virus titers, such as antigen production for diagnostic tests, animal inoculation experiments and vaccine production. The purpose of the present study was to compare the susceptibility of different cell lines for ILTV propagation.

\section{MATERIALS AND METHODS}

Two ILTV strains were tested: LVV13BR was isolated from chickens of São Paulo State (Brazil) and LVV06BR was isolated from turkeys of the South Region of Brazil.

The cells tested were a primary cell culture of chicken embryo fibroblasts (CEF) [12], that was compared with the cell lines: chicken embryo related cells (CER), a cell hybrid derived from chicken embryo fibroblasts cells and BHK-21 (from baby hamster kidney) [19], a chicken fibroblast cell line (HD11) [3], a quail fibroblast cell culture, CEC-32 [23] and a mammalian cell line derived from African green monkey kidney (Vero) [12]. The cells grew into 96 well plates at $37^{\circ} \mathrm{C}$, using an initial concentration of $5.0 \times 10^{5}$ cells $/ \mathrm{mL}$ in Eagle's Minimal Essential Medium (E-MEM) with $200 \mathrm{IU} / \mathrm{mL}$ of Penicillin, final concentration of Streptomycin and supplemented with $5 \%$ fetal calf serum. The HD11 cell line was growing in RPMI supplemented with $10 \%$ fetal calf serum. Both chicken and turkey virus strains were isolated directly from tracheal clinical samples and were grown at least three times in the chorioallantoic membrane (CAM) of embryonated eggs from both species, to increase the titer of the viruses. CAMs were examined for pock formation (opaque plaques on the CAM) at five to seven days post inoculation. Egg infective dose $\left(\mathrm{EID}_{50} /\right.$ $\mathrm{mL}$ ) based on pock formation was $0.2 \times 10^{4}$ [16].

Monolayers were grown in 96-well culture plates until $90 \%$ cell confluence and were inoculated with $50 \mu \mathrm{L}$ of each viral isolate, with eight repetitions. Adsorption was allowed for 40 minutes at $37^{\circ} \mathrm{C}$ and medium with $2 \%$ fetal calf serum was completed to $200 \mu \mathrm{L}$. The plates were incubated at $37^{\circ} \mathrm{C}$ with $5 \%$ $\mathrm{CO}_{2}$. The cells were observed daily during 96 hours for the development of viral cytopathic effect (CPE) using an inverted microscope (Carl-Zeiss, West Germany). The plates were frozen at $-70^{\circ} \mathrm{C}$ until the next passage of the virus. Harvested cultures were centrifuged at $1000 \mathrm{~g}$ for 10 minutes and stored at $70^{\circ} \mathrm{C}$ in small aliquots until required. After three passages in each cell line, supernatants were titrated by the Reed \& Muench method expressed as the $\log _{10}$ tissue culture infective dose per $50 \mu \mathrm{L}\left(\mathrm{TCID}_{50} / 50 \mu \mathrm{L}\right)$.

After each of the three passages, DNA was extracted by the phenol-chloroform method [1]. Two pair of primers were used in a nested-PCR that targets the TK gene of ILTV and amplified a fragment of $647 \mathrm{bp}$ [2].

Statistical analysis were performed using Tukey's test with $1 \%$ of significance and analysis of variance (ANOVA). The analysis were performed using the software package $\mathrm{SAS}^{\circledR}$ (Version 5 Ed. SAS Inst. Inc., Cary, N.C.).

\section{RESULTS}

CER and Vero cell lines were able to replicate ILTV producing viral titers that were not statistically different (Table 1). Primary cell culture of chicken embryo fibroblasts (CEF) was the more susceptible to infection with ILTV producing the highest viral titer $\left(10^{5}\right)$. In contrast, HD11 and CEC-32 cell lines did not produce detectable virus DNA after three passages. The cell lines Vero, CER and CEF were able to replicate both strains of ILTV. The predominant cytophatic effect (CPE) observed was an initial rounding followed by death of the cells. The CPE in CER and CEF cells was observed 24 hours after infection. In addition, the Vero cell line displayed CPE only after 48 or 72 hours of infection. 
Table 1. Titers of virus strains recovered after three passages of ILTV in different cell cultures. Titers were expressed in $\log _{10} \mathrm{TCID}_{50} / 50 \mu \mathrm{L}$. There was no detectable viral yield in HD11 and CEC-32 cell lines.

\begin{tabular}{|c|c|c|}
\hline Cell Line & Field samples & Virus titer \\
\hline CER & LVV13BR & $3.0^{\mathrm{b}}$ \\
\hline & LVV06BR & $3.0^{\mathrm{b}}$ \\
\hline Vero & LVV13BR & $4.0^{\mathrm{b}}$ \\
\hline & LVV06BR & $3.0^{\mathrm{b}}$ \\
\hline CEF & LVV13BR & $5.0^{\mathrm{a}}$ \\
\hline & LVV06BR & $4.0^{\mathrm{b}}$ \\
\hline HD11 & LVV13BR & 0 \\
\hline CEC -32 & LVV06BR & 0 \\
\hline & LVV13BR & 0 \\
\hline & LVV06BR & 0 \\
\hline
\end{tabular}

\section{DISCUSSION}

ILTV has been propagated in a variety of primary cell cultures and chicken embryo liver and chicken embryo kidney cells being the preferred substrates [12]. In the present study, five cell cultures were tested to analyze the replication of ILTV. The cell lines HD11 and CEC-32 were not able to replicate ILTV. CEF and Vero cells were efficient to replicate ILTV, although they produced low viral titers as previously described $[10,11]$. The CER cell line was never tested before for the susceptibility to ILTV, however, it was shown to be susceptible for infectious bursal disease virus, rabies virus and other viruses from mammals $[5-7,19]$. CER produced low viral titers and was able to induce CPE 24 hours after virus inoculation. Therefore, CEF, Vero and CER cell cultures displayed to be poor substrates for ILTV propagation, but all of them were able to replicate both turkey and chicken strains of ILTV $[12,20]$. The macrophage cell line (HD11) was not able to replicate ILTV, although a previous study showed that macrophage cultures were susceptible to ILTV infection, although replication of most ILTV strains was restricted [4]. The cell line CEC-32 is closely related to CEF cell culture, but it seems to be derived from quail [23], a species that is not susceptible to ILTV infection.

The use of two different strains is based on the knowledge that some strains are difficult to replicate in cells that the majority of the strains grow readily. For example, a low pathogenic strain of ILTV isolated from poultry companies at southeast of United States was not able to replicate in primary chicken embryo liver or kidney cells as well as several continuous cell lines [17]. Presumably, erroneous structures as formation of viral particles without nucleocapsids are in part responsible for the low titers of ILTV in tissue culture, witch rarely exceeds one infection unit per cell [8]. In these cases, the PCR technique is a very important means of detection, since it can be used to test samples from suspected birds prior to the inoculation in embryonated eggs or cell cultures and it allows the detection of infection in a very early phase when compared with serological reactions [15].

Although primary cell cultures are still used as hosts for ILTV, they cannot be maintained in vitro for a long time and Specific Pathogen Free (SPF) eggs are very expensive [12]. The replication cycle of ILTV has only been poorly investigated up to now and the knowledge of fundamental mechanisms of virus replication are still hampered by the lack of suitable cell lines for efficient in vitro propagation and manipulation [8].

This is the first report that compares the viral replication of ILTV in HD11, CER and CEC-32 cell lines. Specially, the CER cell line may be easily maintained in the laboratory and is susceptible to a wide spectrum of different viruses. Nevertheless, further experiments with other strains of ILTV with other cell cultures might also contribute to the establishment of a suitable cell line for ILTV propagation and diagnosis. 


\section{CONCLUSIONS}

The cell lines CEC-32 and HD11 were not able to replicate ILTV. The cell cultures CEF and Vero, as already exposed, supported ILTV propagation, although they produced low viral titers. The results indicate that the CER cell line can be used for primary isolation and replication of ILTV.

Acknowledgements. Financial support was provided by Conselho Nacional de Desenvolvimento Científico e Tecnológico (CNPq) and Fundação de Amparo a Pesquisa do Estado do Rio Grande do Sul (FAPERGS).

\section{REFERENCES}

1 Abbas F. \& Andreasen J.R. 1996. Comparison of diagnostic tests for infectious laryngotracheitis. Avian Diseases. 40: 290295.

2 Beltrão N., Furian T.Q., Leão J.A., Pereira R.A., Moraes L. \& Canal C.W. 2004. Detecção do vírus da laringotracheíte das galinhas no Brasil. Pesquisa Veterinária Brasileira. 24: 85-88.

3 Beug H., Von Kirchbach A., Döderlein G. \& Francois J. 1979. Chicken hematopoietic cells transformed by seven strains of defective avian leukemia viruses display three distinct phenotypes of differentiation. Cell. 18: 375-390.

4 Calnek B.W., Fahey K.J. \& Bagust T.J. 1986. In vitro infection studies with infectious laryngotracheitis virus. Avian Diseases. 30: 327-336.

5 Cardoso, T.C., Rahal, P., Pilz, D., Teixeira, M.C.B. \& Arns, C.W. 2000. Replication of classical infectious bursal disease virus in the chicken embryo related cell line. Avian Pathology. 29: 213-217.

6 Cardoso T.C., Silva L.H., Albas A., Ferreira H.L. \& Perri S.H. 2004. Rabies neutralizing antibody detection by indirect immunoperoxidase serum neutralization assay performed on chicken embryo related cell line. Memórias do Instituto Oswaldo Cruz. 99: 531-534.

7 El Karamany R.M., Imam I.Z., Fraid A.H. \& Saber M.S. 1979. Susceptibility of CER cell line to Rift Valley fever virus. Journal of Egypt Public Health Association. 54: 105-114.

8 Fuchs W., Veits J., Helferich D., Granzow H., Teifke J.P. \& Mettenleiter T.C. 2007. Molecular biology of avian infectious laryngotracheitis virus. Veterinary Researc., 38: 261-279.

9 Gama N. 2004. Laringotraqueite: o caso brasileiro. In: Conferência APINCO 2004 de Ciência e Tecnologia Avícolas (São Paulo-Brasil). Campinas: FACTA, pp.85-92.

10 Guy J.S. \& Bagust T.J. 2003. Laryngotracheitis. In: Barnes H.J., Fadly A.M., Glisson J.R., McDougald L.R., Swayne D.E. (Eds). Diseases of Poultry. Ames:Iowa State University Press, pp.121-134.

11 Hidalgo H. 2003. Infectious Laryngotracheitis: A Review. Brazilian Journal of Poultry Science. 5: 157-168.

12 Hughes C.S. \& Jones R.C. 1988. Comparison of cultural methods for primary isolation of infectious laryngotracheitis virus from field materials. Avian Pathology. 17: 295-303.

13 Jonhson M.A. \& Tyack S.G. 1995. Molecular evolution of infectious laryngotracheitis virus (ILTV: Gallid herpesvirus 1): An ancient example of Alphaherpesviridae? Veterinary Microbiology. 46: 221-231.

14 Oldoni I. \& Garcia M. 2007. Caracterização dos vírus da laringotraqueíte infecciosa (VLTI) isolados nos Estados Unidos por PCR-RFLP de múltiplas regiões genômicas. In: XX Congresso Latinoamericano de Avicultura. (Porto Alegre, Brasil) pp.107-109.

15 Pang Y., Wang H., Girshick T., Xie Z. \& Khan M. 2002. Development and application of a multiplex polymerase chain reaction for avian respiratory agents. Avian Diseases. 46: 691-699.

16 Reed L.J. \& Muench H. 1938. A simple method of estimating fifty percent endpoints. American Journal of Hygiene. 27: 493-497.

17 Schnitzlein W.M., Radzevicius, J. \& Tripathy D.N. 1994. Propagation of infectious laryngotracheitis virus in an avian liver cell line. Avian Diseases. 38: 211-217.

18 Sellers H.S., Garcia M., Glisson J.R., Brown T.P., Sander J.S. \& Guy J.S. 2004. Mild infectious laryngotracheitis in broilers in the southeast. Avian Diseases. 48: 430-436.

19 Silva G.M.M. \& Ristow L.E. 2007. Detecção de anticorpos contra laringotraqueíte infecciosa das aves no Estado de Minas Gerais. In: XX Congresso Latinoamericano de Avicultura. (Porto Alegre, Brasil). pp.110-112.

20 Spilki F.R., Almeida R.S., Campalans J. \& Arns C.W. 2006. Susceptibility of different cell lines to infection with bovine respiratory syncytial virus. Journal of Virological Methods. 131: 130-133. 
Portz C., Almeida L.L., Bianco J r A., Reck H., Franco A.C. \& Canal C.W. Comparação de diferentes cultivos celulares para a replicação do vírus da laringotraqueíte...

21 Vargas R.E.S. 1995. Laringotraqueite infecciosa das aves: Estudo epidemiológico em plantéis avícolas no Estado do Rio Grande do Sul. 2000. 106f. Dissertação (Mestrado em Ciências Veterinárias) - Universidade Federal do Rio Grande do Sul, Porto Alegre, 2000.

22 Veits J., Köllner B., Teifke J.P., Granzow H., Mettenleiter T.C. \& Fuchs W. 2003. Isolation and characterization of monoclonal antibodies against structural proteins of infectious laryngotracheitis virus. Avian Diseases. 47: $330-342$.

23 Zöller B., Redman-Muller I., NandaI., Guttenbach M., Dosch E., Schmid M., Zoorob R. \& Jungwirth C. 2000. Sequence comparison of avian interferon regulatory factors and identification of the avian CEC-32 cell as a quail cell line. Journal of Interferon Cytokine Research. 20: 711-717.

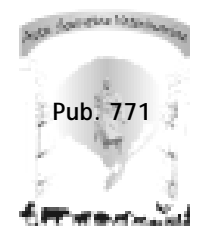

